\title{
Interfering RNA with multi-targets for efficient gene suppression in HCC cells
}

\author{
TIEJUN LI ${ }^{1,2}$, YORK YUANYUAN ZHU ${ }^{1,2}$, YI JI ${ }^{1,2}$ and SONGFENG ZHOU ${ }^{1,2}$ \\ ${ }^{1}$ Small RNA Technology and Application Institute, Nantong University; \\ ${ }^{2}$ Biomics Biotechnologies Co., Ltd., Nantong 226016, P.R. China
}

Received May 24, 2016; Accepted January 22, 2018

DOI: $10.3892 / \mathrm{ijmm} .2018 .3557$

\begin{abstract}
RNA interference (RNAi) technology has been widely used in therapeutics development, especially multiple targeted RNAi strategy, which is a better method for multiple gene suppression. In the study, interfering RNAs (iRNAs) were designed for carrying two or three different siRNA sequences in different secondary structure formats (loop or cloverleaf). By using these types of iRNAs, co-inhibition of survivin and B-cell lymphoma-2 (Bcl-2) was investigated in hepatocellular carcinoma (HCC) cells, and we obtained promising gene silencing effects without showing undesirable interferon response. Furthermore, suppression effects on proliferation, invasion, and induced apoptosis in HCC cells were validated. The results suggest that long iRNAs with secondary structure may be a preferred strategy for multigenic disease therapy, especially for cancer and viral gene therapy and their iRNA drug development.
\end{abstract}

\section{Introduction}

RNA interference (RNAi) has shown tremendous potential in medicinal therapeutics development in past decade (1-4). Now, it has been confirmed that RNAi has great potential in treatment of various human diseases, such as viral infections (5,6), cancers (7-10) and orphan disease (11). Recently, an attempt using a long double-strand siRNA was made, as an alternative way, to carry on multiple interfering RNAs (iRNA) for multiple gene suppression for treatment of many human diseases (12-14), such as therapy for hepatocellular carcinoma (HCC) (10). Currently there are more than thirty types of siRNA drug candidates entered into the stage of clinical trials (15-17). However, these synthetic therapeutic long siRNA

Correspondence to: Dr York Yuanyuan Zhu, Small RNA Technology and Application Institute, Nantong University, 76 Changxing Road, E\&T Development Area, Nantong 226016, P.R. China

E-mail: yzhu@biomics.cn

Key words: multi-target interfering RNAs, small interfering RNA, hepatocellular carcinoma, therapeutic constructs in literature, including our previously study (18), were all based on a primary structure format (linearlized). It is a well-known fact that the longer the RNA molecule is, the easer the degradation occurs during RNA processing in circulation or in cell level.

To stabilize long therapeutic RNA, in the study we first described a group of long synthetic iRNA with multiple siRNA targets in secondary structures (loop or cloverleaf) and applied them to HCC cells for multiple gene suppression.

\section{Materials and methods}

Cell lines and cell culture. SMMC-7721 was cultured in Dulbecco's modified Eagle's medium (DMEM) supplemented with $10 \%$ fetal bovine serum (FBS), 2 mM L-glutamine, $100 \mathrm{U} / \mathrm{ml}$ of penicillin and $100 \mu \mathrm{g} / \mathrm{ml}$ of streptomycin (all from Thermo Fisher Scientific, Waltham, MA, USA). These cell lines were purchased from the Institute of Cell Biology, Chinese Academy of Sciences, and cells were maintained at $37^{\circ} \mathrm{C}$ with $5 \% \mathrm{CO}_{2}$ and $95 \%$ air in a humidified incubator.

Multi-target iRNA format design and transfection. The gene sequence of survivin (accession no. NM_001168) and B-cell lymphoma-2 (Bcl-2) (accession no. NM_000633.2) were obtained from National Center of Biotechnology Information (NCBI) GenBank (USA), and the single target siRNA (19 bp duplex with 2-nt 3'-overhangs) targeting either survivin or Bcl-2 were screened in our precious studies (Table I) $(18,19)$. A double-stranded RNA sequence with no homology with human genes was designed as siRNA negative control (NC_ siR). All RNA oligonucleotides were synthesized by Biomics Biotechnologies Co., Ltd. (Nantong, China). The multi-target iRNA constructs targeting survivin and $\mathrm{Bcl}-2$ were designed according to the principle of Biomics Biotechnologies Co., Ltd. (Table II). The cells were transfected in vitro with siRNAs using Lipofectamine ${ }^{\circledR} 2000$ transfection reagent (Thermo Fisher Scientific) according to the instructions of the manufacturer.

Real-time quantitive PCR (RT-qPCR). Total RNA of cells were extracted by RISO ${ }^{\mathrm{TM}}$ RNA extraction reagent (Biomics Biotechnologies Co., Ltd.) and then performed in a RT-qPCR reaction: $12.5 \mu \mathrm{l}$ of $2 \mathrm{X}$ One-Step qPCR Mix (Biomics Biotechnologies Co., Ltd.), $0.5 \mu$ l of each forward and reverse 
Table I. Sequences of the single target siRNAs.

\begin{tabular}{|c|c|c|c|}
\hline \multicolumn{2}{|l|}{ siRNAs } & \multicolumn{2}{|r|}{ Primer sequences $\left(5^{\prime}-3^{\prime}\right)$} \\
\hline Survivin siRNA1 & S2 & Sense & GACUUGGCCCAGUGUUUCUdTdT \\
\hline & & Antisense & AGAAACACUGGGCCAAGUCdTdT \\
\hline \multirow[t]{2}{*}{ Survivin siRNA2 } & S38 & Sense & UCCUUUCUGUCAAGAAGCAGUUdTdT \\
\hline & & Antisense & AACUGCUUCUUGACAGAAAGGAdTdT \\
\hline \multirow[t]{2}{*}{ Bcl-2 siRNA } & B2 & Sense & GGAUGACUGAGUACCUGAAdTdT \\
\hline & & Antisense & UUCAGGUACUCAGUCAUCCdTdT \\
\hline \multirow[t]{2}{*}{ Negative control siRNA } & NC_siR & Sense & UUCUCCGAACGUGUCACGUdTdT \\
\hline & & Antisense & ACGUGACACGUUCGGAGAAdTdT \\
\hline
\end{tabular}

NC_siR, siRNA negative control; Bcl-2, B-cell lymphoma-2.

Table II. Sequences of RT-qPCR primers.

\begin{tabular}{|c|c|}
\hline Gene name & Primer sequences $\left(5^{\prime}-3^{\prime}\right)$ \\
\hline Survivin & $\begin{array}{l}\text { F: CGACGTTGCCCCCTGCCTG } \\
\text { R: AAGGAAAGCGCAACCGGACGA }\end{array}$ \\
\hline Bcl-2 & $\begin{array}{ll}\text { F: } & \text { GGCTGGGATGCCTTTGTG } \\
\text { R: } & \text { GCCAGGAGAAATCAAACAGAGG }\end{array}$ \\
\hline Ago2 & $\begin{array}{l}\text { F: GGCAGGAAGAATCTATACAC } \\
\text { R: CTTGATGGACACCTTGAAG }\end{array}$ \\
\hline OAS1 & $\begin{array}{l}\text { F: GTGAGCTCCTGGATTCTGCT } \\
\text { R: }\end{array}$ \\
\hline IFIT1 & $\begin{array}{ll}\text { F: } & \text { AATAGACTGTGAGGAAGGATGG } \\
\text { R: } & \text { TCCAGGCGATAGGCAGAG }\end{array}$ \\
\hline GAPDH & $\begin{array}{l}\text { F: GAAGGTGAAGGTCGGAGTC } \\
\text { R: GAAGATGGTGATGGGATTTC }\end{array}$ \\
\hline
\end{tabular}

Bcl-2, B-cell lymphoma-2; GAPDH, glyceraldehyde 3-phosphate dehydrogenase; F, forward; $\mathrm{R}$, reverse.

primers (10 $\mu \mathrm{M}$ each; Biomics Biotechnologies Co., Ltd.), $0.5 \mu 1$ of 50X SYBR-Green I and $4 \mu 1$ total RNA was then subjected to reverse transcription for $30 \mathrm{~min}$ at $42^{\circ} \mathrm{C}$ and initially denatured at $95^{\circ} \mathrm{C}$ for $5 \mathrm{~min}$, and then to 45 cycles of amplification with the condition of $95^{\circ} \mathrm{C}$ denaturation for $20 \mathrm{sec}, 55^{\circ} \mathrm{C}$ annealing for $30 \mathrm{sec}$, and $72^{\circ} \mathrm{C}$ extension for $30 \mathrm{sec}$. Human glyceraldehyde 3 -phosphate dehydrogenase (GAPDH) served as an internal control. The experiment was performed in triplicate. All primer sequences are shown in Table II. The results were analyzed by $2^{-\Delta \Delta C t}$ method (20).

Western blotting. Cells were plated in a 6 -well plate at $1 \times 10^{6}$ cells/well and grown for $24 \mathrm{~h}$ until $~ 70-80 \%$ confluence. After cells were treated as described above for $48 \mathrm{~h}$, they were harvested and lysed in RIPA buffer (Pierce, Rockford, IL, USA). Total protein was quantified by bicinchoninic acid (BCA) assay (Promega, Madison, WI, USA), and then $\sim 20 \mu \mathrm{g}$ of protein was separated by polyacrylamide gel electrophoresis (PAGE) and electroblotted onto polyvinylidine difluoride filter (PVDF) membranes (Millipore, Billerica, MA, USA), followed by blocking with 5\% skim milk in TBST (20 mM Tris, $150 \mathrm{mM} \mathrm{NaCl}, 0.05 \%$ Tween-20, $\mathrm{pH} 7.5$ ) buffer for $2 \mathrm{~h}$ at room temperature, then incubated with rabbit anti-human survivin antibody (1:500 dilution) and mouse anti-human Bcl-2 (1:500 dilution), mouse anti-human $\beta$-actin antibody (1:500 dilution) (all from Abcam, Cambridge, MA, USA) as internal control. The membranes were washed in TBST and incubated with a goat anti-rabbit or goat anti-mouse HRP-conjugated secondary antibody (1:1,000 dilution; Jackson Immunoresearch, West Grove, PA, USA) at room temperature for $2 \mathrm{~h}$. Then, the specific proteins were detected with ECL chemiluminescence reagent (Beyotime, Beijing, China); the membranes were exposed to film (Kodak, Rochester, NY, USA).

Cell viability assay. MTT assay was used to measure the viability of cells. Cells were plated into a 96 -well plate at $5 \times 10^{3}$ cells/well and grown for $24 \mathrm{~h}$, then treated as above for 0 , 24, 48, 72 and 96 h, $10 \mu 1$ MTT (Beyotime) were added to each well of 96-well plate containing $100 \mu \mathrm{l}$ DMEM medium and incubated at $37^{\circ} \mathrm{C}$ for $4 \mathrm{~h}$, then $150 \mu \mathrm{l} /$ well DMSO was added and incubation was continue at $37^{\circ} \mathrm{C}$ for $10 \mathrm{~min}$. The optical density (OD) was measured at $490 \mathrm{~nm}$ using a Microplate Reader (Bio-Rad, Hercules, CA, USA).

Cell invasion assay. Cells were seeded into a 24 -well plate at $2 \times 10^{4}$ cells/well and grown for $24 \mathrm{~h}$, then treated as described above, post $48 \mathrm{~h}$ treament, cells were suspended in DMEM medium at the density of $1 \times 10^{6}$ cells $/ \mathrm{ml}$. Briefly, Transwell chambers (Corning, Inc., Corning, NY, USA) and treated with DMEM for $1 \mathrm{~h}$ before treatments; an $8 \mu \mathrm{m}$ pore polycarbonate membrane was coated with $50 \mu 1$ of $0.5 \mathrm{mg} / \mathrm{ml}$ Matrigel (BD Biosciences, San Jose, CA, USA) and used to separate the upper and lower chambers. Cell suspension (100 $\mu \mathrm{l})$ was added into each upper chamber and $600 \mu \mathrm{l}$ DMEM containing $10 \%$ FBS or conditioned medium which was the cell supernatant with siRNAs post-transfected for $48 \mathrm{~h}$. The cells on the top surface of the membrane were carefully removed at $24 \mathrm{~h}$ post treatments. Cells on the Transwell chambers were fixed for $30 \mathrm{sec}$ in $10 \%$ formaldehyde, and then stained by $0.5 \%$ crystal violet, after washing by phosphate-buffered saline (PBS), the cells on the top surface of the membrane were carefully removed again. The cells on the bottom surface of the membrane were counted in 3-5 random fields under a microscope (magnification, x100). 


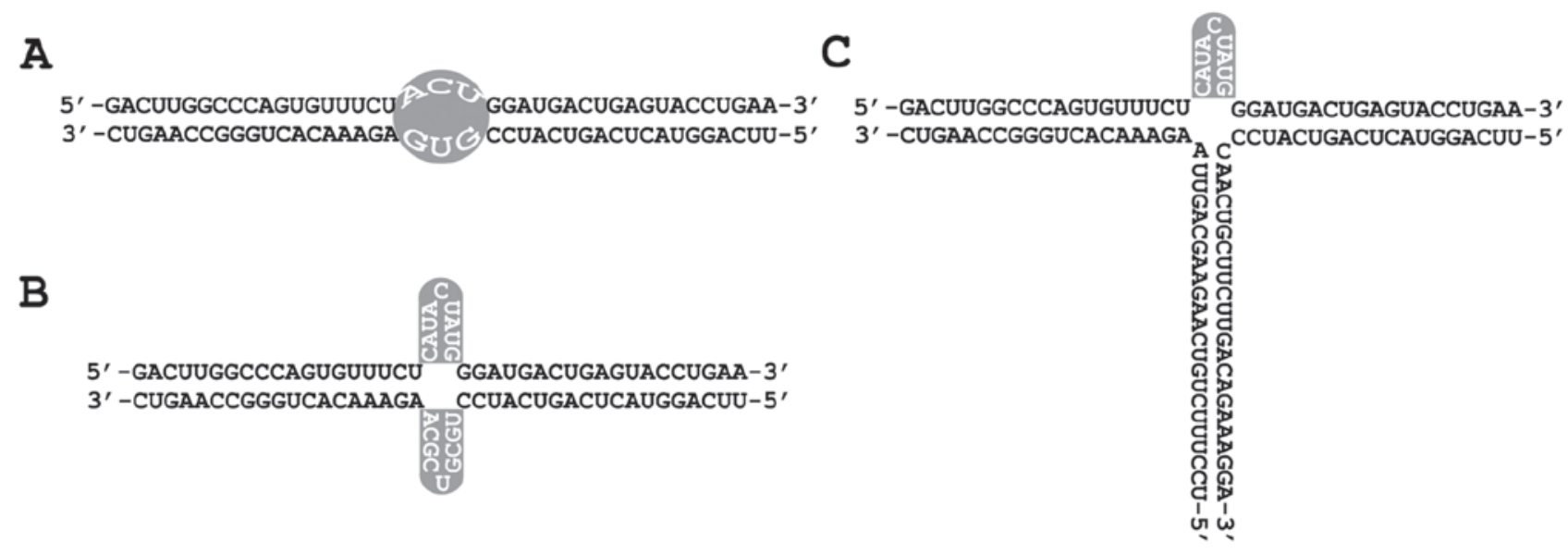

Figure 1. The structures of different multi-target interfering RNAs (mtg_iRNA). (A) mtg_iRNA1; (B) mtg_iRNA2; (C) mtg_iRNA3.

Cell apoptosis assay. Annexin V-FITC/PI double staining and flow cytometry (FCM) analysis method was used to determine cell apoptosis. Briefly, $1 \times 10^{6}$ cells/well in a 6 -well plate treated with different treatments as above for $48 \mathrm{~h}$ were harvested and washed in PBS, cells were stained by using Annexin V-FITC apoptosis detection kit (Sigma-Aldrich, St. Louis, MO, USA), then detected by FCM analysis (BD Biosciences).

Statistical analysis. All experiments were performed independently three times, the results are shown as mean \pm standard deviation (SD), and statistical analyses were performed using SPSS 19.0 software. The differences were compared using Student's t-test and one way ANOVA followed by post hoc test to assess statistical significance. All P-values were based on a two-sided statistical analysis and $\mathrm{P}<0.05$ was considered to indicate statistical significance.

\section{Results}

Designing different multi-target iRNAs. Multi-target iRNAs targeting survivin and Bcl-2 were designed according to different structure formats (Fig. 1). The sense and antisense strands of iRNAs were synthesized by Biomics Biotechnologies Co., Ltd. and iRNAs were obtained after annealing of both strands (Table II and Fig. 1).

Inhibition effects of target genes in HCC cells by multi-target $i R N A s$. The result of RT-qPCR and western blot analysis showed that, compared with untreated cell, the mRNA and protein level of survivin were both inhibited by survivin siRNA (S2 or S38). The mRNA and protein level of Bcl-2 were both inhibited by Bcl-2 siRNA (B2) $(\mathrm{P}<0.05)$ (Fig. 2).

Compared to untreated group, the mRNA level of survivin was inhibited by multi-target interfering RNAs (mtg_iRNA1), mtg_iRNA2 and mtg_iRNA3 up to 45, 27 and $53 \%(\mathrm{P}<0.05)$ (Fig. 3A); the mRNA level of Bcl-2 was inhibited up to 38, 27 and 33\% $(\mathrm{P}<0.05)$ (Fig. 3B); and there was no difference between NC_siRNA and untreated ones. Moreover, mtg_iRNA1, mtg_iRNA2 and mtg_iRNA3 showed no interferon response (Fig. 3C). The protein level of survivin was inhibited by mtg_iRNA1, mtg_iRNA2 and mtg_iRNA3 up to 48,46 and $68 \%$, respectively $(\mathrm{P}<0.05)$; the protein level of Bcl-2 was inhibited up to 45,57 and $48 \%(\mathrm{P}<0.05)$, and there was no difference between NC_siR and untreated group (P>0.05) (Fig. 3D).

Gene knockdown by mtg_iRNAs in an Ago2-dependent manner. Long double-stranded RNA was reported with gene knockdown effect in an Ago2-dependent manner (21). To verify the manner of the effect of mtg_iRNAs, the Ago2 siRNA (sense, 5'-AAUCUCUUCUUGCCGAUCGdTdT-3' and antisense, 5'-CGAUCGGCAAGAAGAGAUUdTdT-3') was used to knockdown the expression of Ago2, and we further investigated whether mtg_iRNAs could downregulate the target genes. As shown in Fig. 3, compared with untreated cells, the expression of Ago2 was inhibited efficiently by Ago2_siR, when Ago2 was downregulated, target gene survivin or Bcl-2 could not be inhibited by mtg_iRNAs, and thus gene knockdown by mtg_iRNAs was Ago2-dependent (Fig. 3E).

Inhibition effects on cell viability by multi-target siRNAs. The viability of SMMC-7721 cells was measured by MTT assay. The absorbance values $(490 \mathrm{~nm})$ of the cells at 48, 72 and $96 \mathrm{~h}$ post-transfection with mtg_iRNA1, mtg_iRNA2 and mtg_iRNA3 were significantly lower than those of NC_siR treated and untreated cells, respectively $(\mathrm{P}<0.05)$ (Fig. 4). There was no significant difference between NC_siR treated and untreated cells $(\mathrm{P}>0.05)$.

Inhibition effects on cell invasion by multi-target siRNAs. The cell invasion abilities with different treatments were detected by Transwell assay, the result showed that the invasion of the cells treated with mtg_iRNA1, mtg_iRNA2 and mtg_iRNA3 were inhibited significantly post $48 \mathrm{~h}$ transfection $(\mathrm{P}<0.05)$. There was no significant difference of inhibition abilities between NC_siR and untreated cells (P>0.05) (Fig. 5).

Cell apoptosis induces multi-target siRNAs. Annexin V-FITC/ PI double staining and FCM analysis were used to detect the ability of mtg_iRNAs on inducing SMMC-7721 cell apoptosis. The result showed that cells treated with mtg_iRNA1, $20.52 \pm 0.81 \%, \mathrm{mtg} \_$iRNA2, 22.36 $\pm 1.15 \%$ and $\mathrm{mtg}$ _iRNA3, 

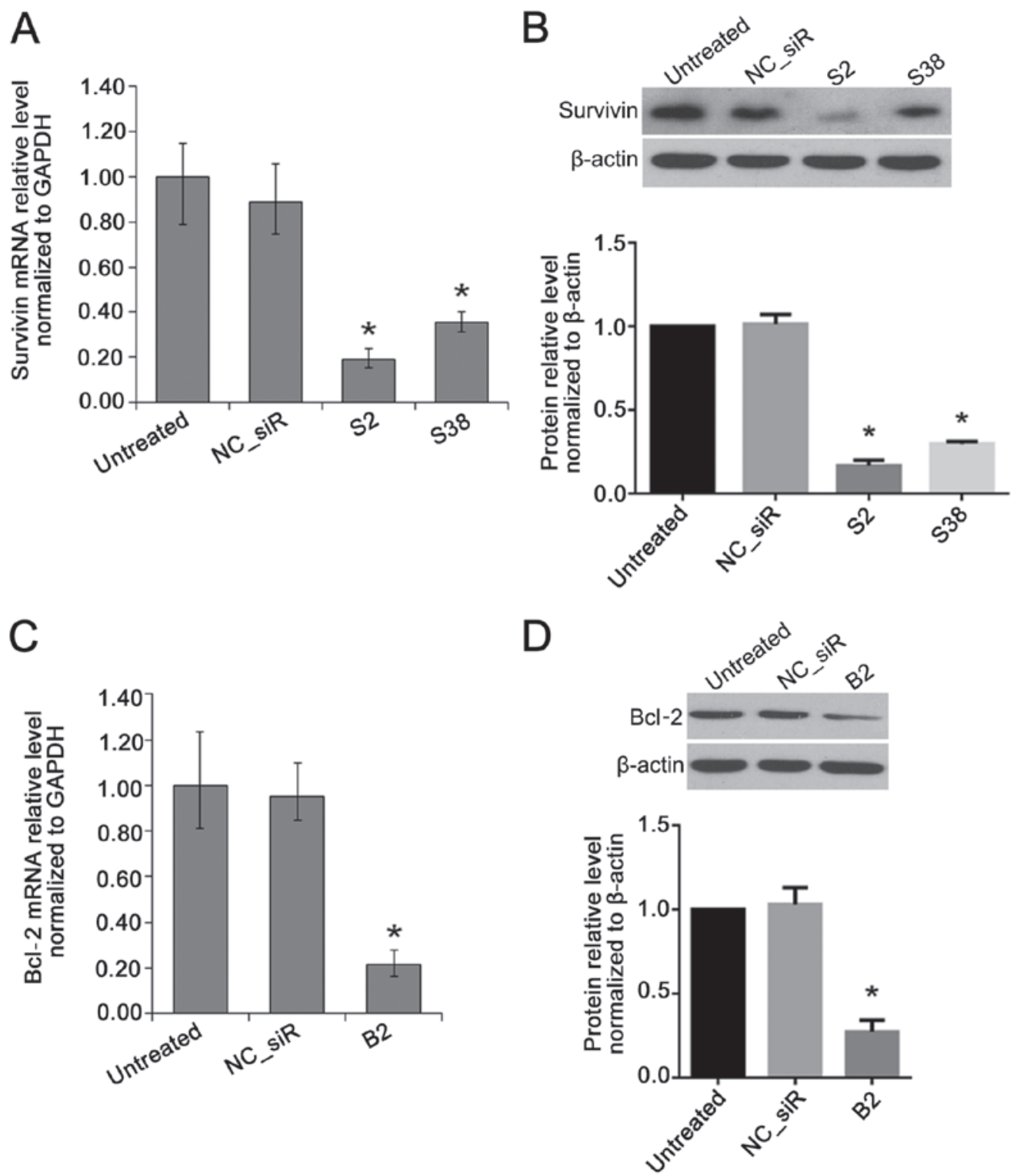

Figure 2. Inhibition effects on survivin or Bcl-2 by single target siRNA in hepatocellular carcinoma (HCC) cells. (A) The mRNA expression level of survivin inhibited by $\mathrm{S} 2$ or $\mathrm{S} 38$ siRNA detected by RT-qPCR, ${ }^{\circ} \mathrm{P}<0.05$ vs. untreated cells. (B) The mRNA expression level of Bcl-2 inhibited by B2 siRNA detected by RT-qPCR, "P<0.05 vs. untreated cells. (C) The protein expression level of survivin inhibited by S2 or S38 siRNA detected by western blotting, ${ }^{*} \mathrm{P}<0.05$ vs. untreated cells. (D) The protein expression level of Bcl-2 inhibited by B2 siRNA detected by western blotting, ${ }^{*} \mathrm{P}<0.05$ vs. untreated cells.

$38.79 \pm 1.63 \%$ resulted in a significant increase of apoptosis compared with that of NC_siR treated cells, $1.96 \pm 1.35 \%$ and untreated cells, $1.52 \pm 1.41 \%(\mathrm{P}<0.05)$ (Fig. 6).

\section{Discussion}

The present study is the first attempt to use long synthetic iRNA formats (loop or cloverleaf) to carry multiple siRNA targets. Survivin and Bcl-2 were used as HCC therapeutic targets in our study for iRNA therapeutics development. survivin is an apoptosis inhibitor that is expressed during the G2/M phase of the cell cycle and it is a member of the inhibitor of apoptosis (IAP) gene family, survivin encodes negative regulatory proteins that prevent apoptotic cell death (25). Bcl-2 is specifically considered as an important anti-apoptotic oncogene, and it is the founding member of the Bcl-2 family of regulator proteins that regulate cell death $(26,27)$.
The efficiency of gene co-inhibition by long secondary structure iRNA was demonstrated (Fig. 3A, B and D), in which all three mtg_iRNAs inhibited target genes (survivin or Bcl-2) effectively in both mRNA and protein level.

The side-effect of undesired interferon response caused long double-stranded RNA (dsRNA) is a major concern. It was addressed by a previous study indicating that specific gene knockdown via RNAi triggered by long dsRNA could induce interferon response (28), thus the expression of OAS1 and IFIT1 were detected to monitor the interferon response and a synthetic dsRNA analog-poly(I:C) was used as positive control (29). The designed long secondary structure iRNAs here had no obvious interferon response in mammalian cells (Fig. 3C). RNAi effects can be triggered by different structural modifications of siRNA, also long multi-target based siRNA structures designed as Dicer substrates have been developed in therapeutic research (19), and these siRNAs 


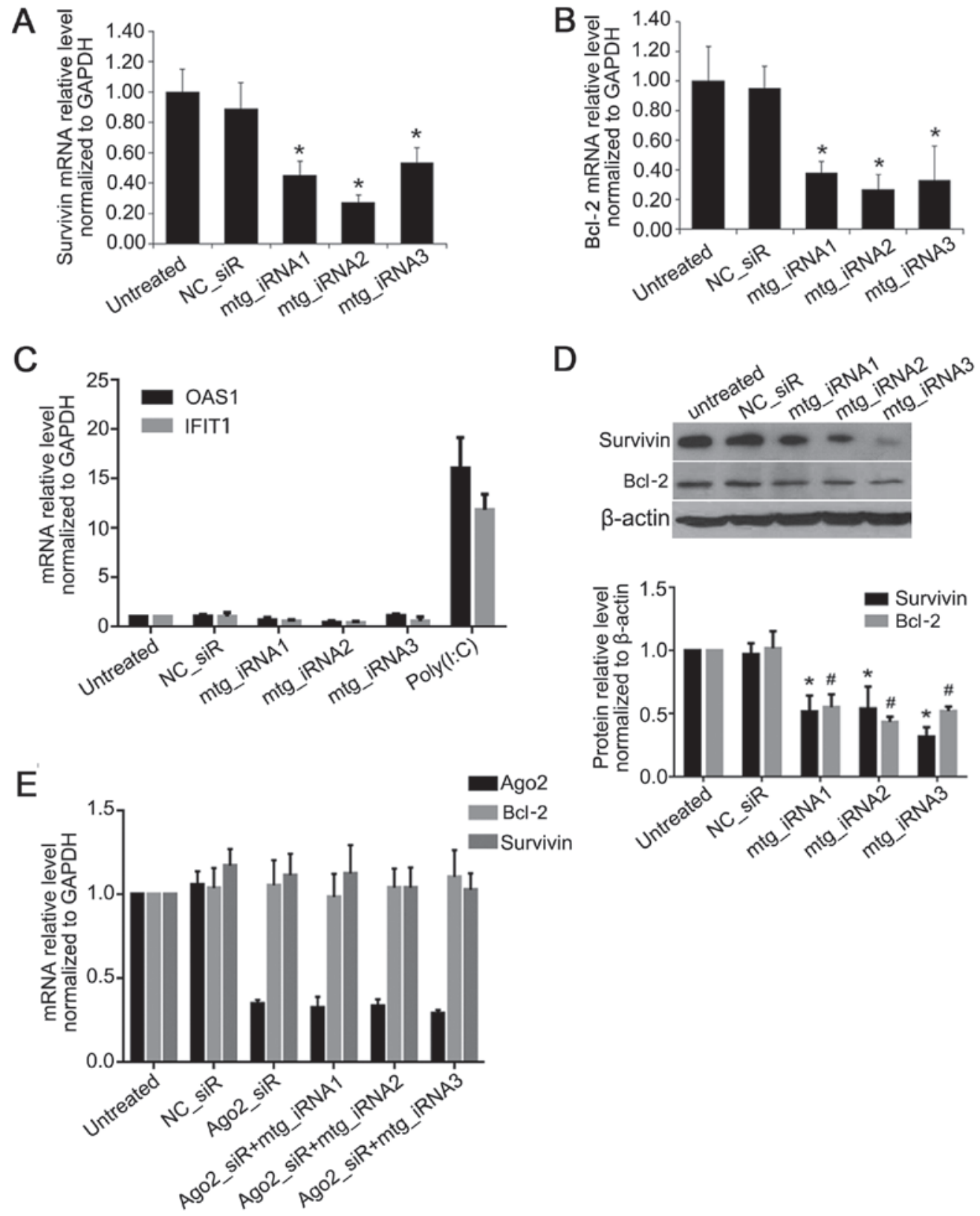

Figure 3. Inhibition effects on survivin or Bcl-2 by multi-target interfering RNAs (mtgRNAs) in hepatocellular carcinoma (HCC) cells. (A) The mRNA expression level of survivin inhibited by mtg_iRNA1, mtg_iRNA2 or mtg_iRNA3 detected by RT-qPCR, "P<0.05 vs. untreated cells. (B) The mRNA expression level of Bcl-2 inhibited by mtg_iRNA1, mtg_iRNA2 or mtg_iRNA3 detected by RT-qPCR, "P<0.05 vs. untreated cells. (C) No interferon response induced by $\mathrm{mtg} \_i R N A 1, m t g \_i R N A 2$ or mtg_iRNA3. (D) The protein expression level of survivin or Bcl-2 inhibited by mtg_iRNA1, mtg_iRNA2 or mtg_iRNA3 detected by western blotting, ${ }^{*} \mathrm{P}<0.05$ the protein level of survivin and ${ }^{\#} \mathrm{P}<0.05$ the protein level of Bcl-2 vs. untreated cells. (E) The mRNA expression level of survivin or Bcl-2 by mtg_iRNAs when Ago2 was downregulated.

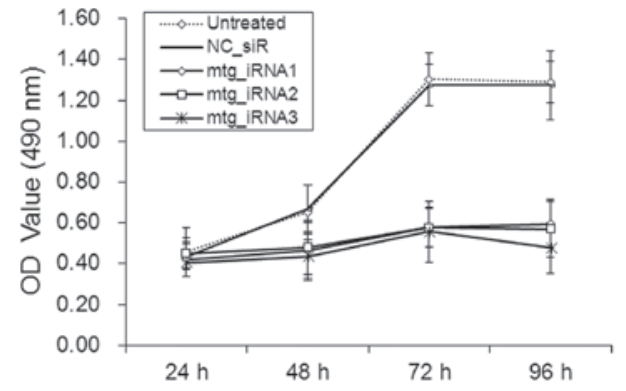

Figure 4. Inhibition effects on cell viability by multi-target interfering RNAs (mtg_iRNAs) at $0,24,48,72$ and $96 \mathrm{~h}$ detected by MTT assay. The viabilities of cells at 48,72 and $96 \mathrm{~h}$ were inhibited significantly by mtg_iRNA1, mtg_iRNA2 and mtg_iRNA3 compared to those of NC_siR treated and untreated cells. were all Ago2-dependent. In the present study, also our mtg_iRNAs were all Ago2-dependent by the method of Ago2 downregulation first (Fig. 3E). Furthermore, we demonstrated that the proliferation and invasion of HCC cells were inhibited, also cell apoptosis was promoted by mtg_iRNAs effectively (Fig. 4-6). The results of this study demonstrated that the designed mtg_iRNAs construct had RNAi activities on knockdown target genes simultaneously. The results showed that, mtg_iRNAs may be a preferred strategy for multigenic disease therapy, especially in cancer.

In conclusion, the long iRNA with different formats (loop and cloverleaf) showed initial multi-gene co-inhibition effects without showing side-effect of interferon 


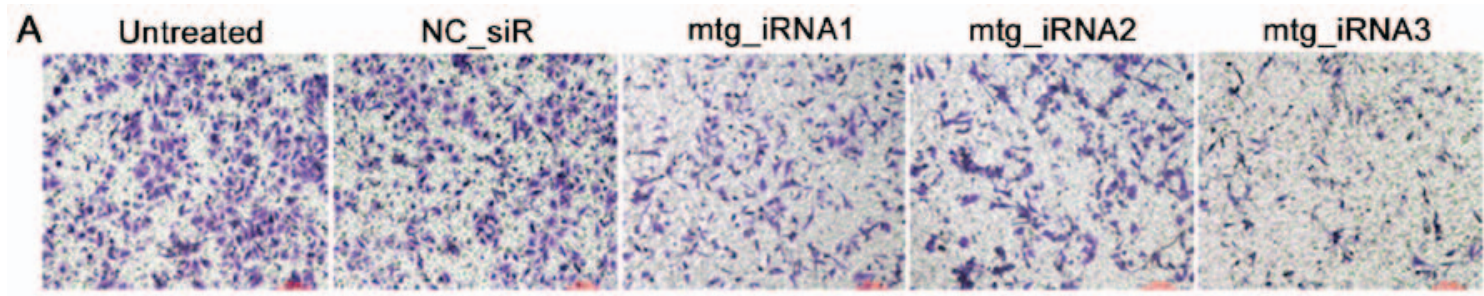

B

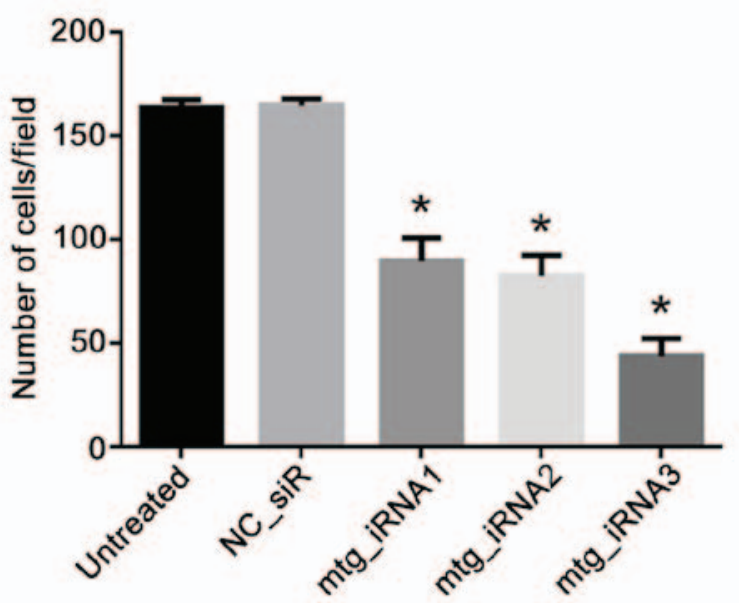

Figure 5. Inhibition effects on cell invasion by multi-target interfering RNAs (mtg_iRNAs) detected using Transwell chamber assay. (A) The representative figures of cells with different treatments detected by Transwell chamber assay. (B) The invasions of cells were inhibited significantly by mtg_iRNA1, mtg_iRNA2 and mtg_iRNA3 $(\mathrm{P}<0.05)$.

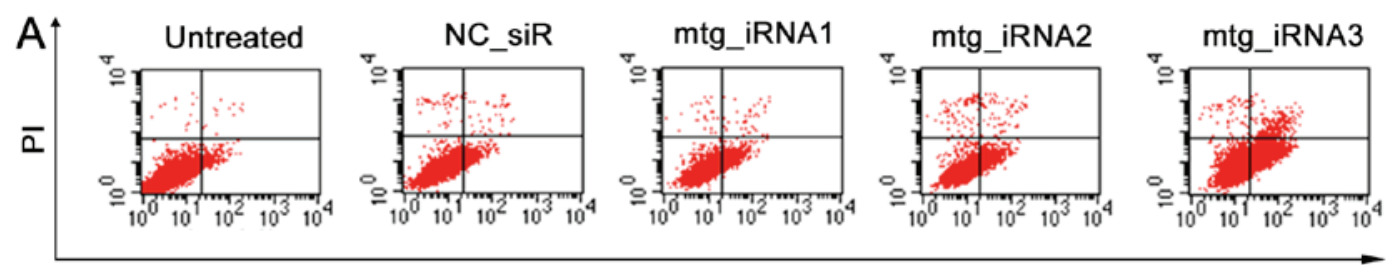

Annexin V

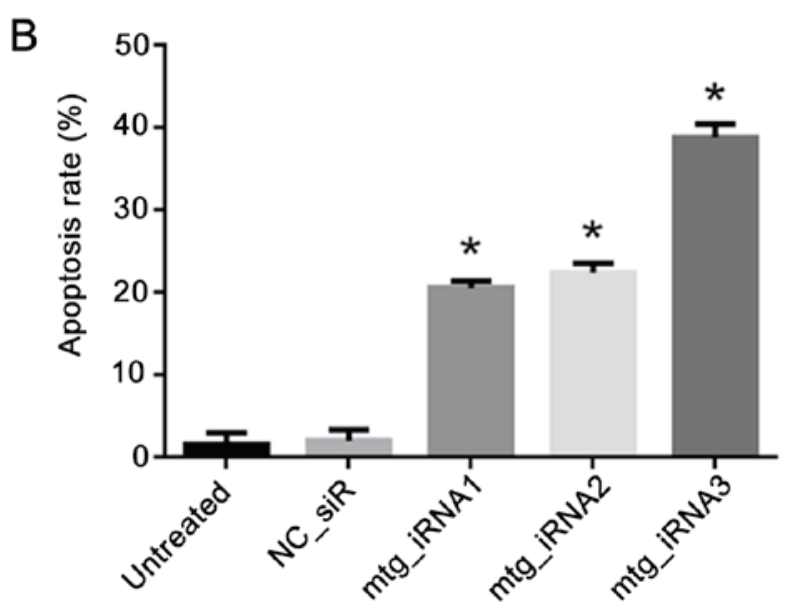

Figure 6. Effects on cell apoptosis by multi-target interfering RNAs (mtg_iRNAs) measured by flow cytometry (FCM) analysis after Annexin V/PI staining. (A) The representative figures of cells with different treatments detected by FCM analysis; (B) Increase of cell apoptosis rate induced by mtg_iRNA1, mtg_iRNA2 and mtg_iRNA3 $(\mathrm{P}<0.05)$.

response. The design could be as an alternative way to open its new applications in RNAi based gene therapy and drug development.

\section{Acknowledgements}

Not applicable. 


\section{Funding}

This study was supported by the National High Technology Research and Development Program of China (863 Program, no. 2012AA022501); the National Science and Technology Major Project of China (no. 2013ZX09301303-005).

\section{Availability of data and material}

The datasets used and/or analyzed during the current study are available from the corresponding author on reasonable request.

\section{Authors' contributions}

TL and YYZ designed the study. YYZ designed the different structures of multi-target interfering RNAs. TL, YJ and SZ performed the RT-qPCR, western blot analysis, MTT. TL performed the cell invasion assay and cell apoptosis assay. TL was a major contributor in writing the manuscript; YYZ revised the manuscript and supervised the study. All authors read and approved the final manuscript.

\section{Ethics approval and consent to participate}

Not applicable.

\section{Consent for publication}

Not applicable.

\section{Competing interests}

The authors declare that they have no competing interests.

\section{References}

1. Fire A, Xu S, Montgomery MK, Kostas SA, Driver SE and Mello CC: Potent and specific genetic interference by doublestranded RNA in Caenorhabditis elegans. Nature 391: 806-811, 1998.

2. Chendrimada TP, Gregory RI, Kumaraswamy E, Norman J, Cooch N, Nishikura K and Shiekhattar R: TRBP recruits the Dicer complex to Ago2 for microRNA processing and gene silencing. Nature 436: 740-744, 2005.

3. Hammond SM, Bernstein E, Beach D and Hannon GJ: An RNA-directed nuclease mediates post-transcriptional gene silencing in Drosophila cells. Nature 404: 293-296, 2000.

4. Elbashir SM, Lendeckel W and Tuschl T: RNA interference is mediated by 21- and 22-nucleotide RNAs. Genes Dev 15: 188-200, 2001

5. Chen J, Shi X, Zhang X, Wang L, Luo J, Xing G, Deng R, Yang H, Li J, Wang A, et al: Porcine reproductive and respiratory syndrome virus (PRRSV) inhibits RNA-mediated gene silencing by targeting Ago-2. Viruses 7: 5539-5552, 2015.

6. Nikitenko NA, Speiseder T, Lam E, Rubtsov PM, Tonaeva KhD, Borzenok SA, Dobner T and Prassolov VS: Regulation of human adenovirus replication by RNA interference. Acta Naturae 7: 100-107, 2015.

7. Tai W, Qin B and Cheng K: Inhibition of breast cancer cell growth and invasiveness by dual silencing of HER-2 and VEGF. Mol Pharm 7: 543-556, 2010.

8. Shahzad MM, Lu C, Lee JW, Stone RL, Mitra R, Mangala LS, Lu Y, Baggerly KA, Danes CG, Nick AM, et al: Dual targeting of EphA2 and FAK in ovarian carcinoma. Cancer Biol Ther 8: 1027-1034, 2009.
9. Kim DH, Behlke MA, Rose SD, Chang MS, Choi S and Rossi JJ: Synthetic dsRNA Dicer substrates enhance RNAi potency and efficacy. Nat Biotechnol 23: 222-226, 2005.

10. Tabernero J, Shapiro GI, LoRusso PM, Cervantes A, Schwartz GK, Weiss GJ, Paz-Ares L, Cho DC, Infante JR, Alsina M, et al: First-in-humans trial of an RNA interference therapeutic targeting VEGF and KSP in cancer patients with liver involvement. Cancer Discov 3: 406-417, 2013.

11. Coelho T, Adams D, Silva A, Lozeron P, Hawkins PN, Mant T, Perez J, Chiesa J, Warrington S, Tranter E, et al: Safety and efficacy of RNAi therapy for transthyretin amyloidosis. N Engl J Med 369: 819-829, 2013.

12. Zimmermann GR, Lehár J and Keith CT: Multi-target therapeutics: When the whole is greater than the sum of the parts. Drug Discov Today 12: 34-42, 2007.

13. Li T, Wu M, Zhu YY, Chen J and Chen L: Development of RNA interference-based therapeutics and application of multi-target small interfering RNAs. Nucleic Acid Ther 24: 302-312, 2014.

14. Boyapalle S, Xu W, Raulji P, Mohapatra S and Mohapatra SS: A multiple siRNA-based anti-HIV/SHIV microbicide shows protection in both in vitro and in vivo models. PLoS One 10: $\mathrm{e} 0135288,2015$.

15. Takeshita $\mathrm{F}$ and Ochiya $\mathrm{T}$ : Therapeutic potential of RNA interference against cancer. Cancer Sci 97: 689-696, 2006.

16. Aigner A: Applications of RNA interference: Current state and prospects for siRNA-based strategies in vivo. Appl Microbiol Biotechnol 76: 9-21, 2007.

17. Davidson BL and McCray PB Jr: Current prospects for RNA interference-based therapies. Nat Rev Genet 12: 329-340, 2011.

18. Peng W, Chen J, Qin Y, Yang Z and Zhu YY: Long doublestranded multiplex siRNAs for dual genes silencing. Nucleic Acid Ther 23: 281-288, 2013.

19. Li T, Zhu YY, Chen L, Sun Y, Yuan J, Graham M and French P: Size unbiased representative enzymatically generated RNAi (SURER) library and application for RNAi therapeutic screens. Nucleic Acid Ther 25: 35-46, 2015.

20. Livak KJ and Schmittgen TD: Analysis of relative gene expression data using real-time quantitative PCR and the 2(-Delta Delta C(T)) method. Methods 25: 402-408, 2001.

21. Chang CI, Kang HS, Ban C, Kim S and Lee DK: Dual-target gene silencing by using long, synthetic siRNA duplexes without triggering antiviral responses. Mol Cells 27: 689-695, 2009.

22. Rice RR, Muirhead AN, Harrison BT, Kassianos AJ, Sedlak PL, Maugeri NJ, Goss PJ, Davey JR, James DE and Graham MW: Simple, robust strategies for generating DNA-directed RNA interference constructs. Methods Enzymol 392: 405-419, 2005.

23. Shin D, Lee H, Kim SI, Yoon Y and Kim M: Optimization of linear double-stranded RNA for the production of multiple siRNAs targeting hepatitis C virus. RNA 15: 898-910, 2009.

24. Aviñó A and Ocampo SM: Perales and JC Eritja R: Branched RNA: A new architecture for RNA interference. J Nucleic Acids 586935: 2011.

25. Verdecia MA, Huang H, Dutil E, Kaiser DA, Hunter T and Noel JP: Structure of the human anti-apoptotic protein survivin reveals a dimeric arrangement. Nat Struct Biol 7: 602-608, 2000.

26. Tsujimoto Y, Finger LR, Yunis J, Nowell PC and Croce CM: Cloning of the chromosome breakpoint of neoplastic B cells with the $t(14 ; 18)$ chromosome translocation. Science 226: 1097-1099, 1984.

27. Cleary ML, Smith SD and Sklar J: Cloning and structural analysis of cDNAs for bcl-2 and a hybrid bcl-2/immunoglobulin transcript resulting from the $\mathrm{t}(14 ; 18)$ translocation. Cell 47 : 19-28, 1986.

28. Elbashir SM, Harborth J, Lendeckel W, Yalcin A, Weber K and Tuschl T: Duplexes of 21-nucleotide RNAs mediate RNA interference in cultured mammalian cells. Nature 411: 494-498, 2001.

29. Palchetti S, Starace D, De Cesaris P, Filippini A, Ziparo E and Riccioli A: Transfected poly(I:C) activates different dsRNA receptors, leading to apoptosis or immunoadjuvant response in androgen-independent prostate cancer cells. J Biol Chem 290: 5470-5483, 2015. 